\title{
Uji Emisi Sepeda Motor Honda Supra X 125 Menggunaan Campuran Bioetanol Dari Limbah Nanas Dan Premium
}

\author{
Masykur $^{1}$, Emiliza Satria ${ }^{2}$, Herri Darsan ${ }^{3}$ \\ ${ }^{1)}$ Jurusan Teknik Mesin, Fakultas Teknik Universitas Teuku Umar \\ ${ }^{2}$ Teknik Otomotif, Fakultas Teknik Universitas Negeri Padang \\ 3)Jurusan Teknik Mesin, Fakultas Teknik Universitas Teuku Umar \\ Email: ${ }^{1}$ masykur@utu.ac.id, ${ }^{3}$ herri.darsan@utu.ac.id
}

\begin{abstract}
Penelitian ini bermaksud untuk mengetahui emisi gas buang pada mesin motor Honda Supra X 125 Tahun 2006. Penelitian ini menggunakan metode analisa deskriptif. Bahan bakar yang digunakan adalah premium murni (kelompok standart) dan premium yang dicampur dengan bioetanol dengan variasi E2,5, E5, dan E7,5 (kelompok eksperimen). Pengujian dilakukan pada putaran stasioner (1500 rpm), $3000 \mathrm{rpm}$ sampai $8000 \mathrm{rpm}$ dengan interval $500 \mathrm{rpm}$. Emisi yang

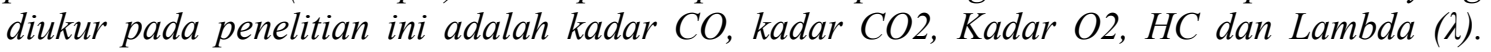
Pengujian dilakukan di Laboratorium Motor Bakar Universitas Negeri Padang. Berdasarkan hasil penelitian dapat disimpulkan pengujian emisi gas buang Sepeda Motor Honda Supra X 125 Tahun 2006 menggunakan bahan bakar campuran bioetanol dari limbah nanas dan premium dapat meningkatkan konsentrasi $\mathrm{CO} 2$ menurunkan konsentrasi $\mathrm{CO}, \mathrm{HC}$ dan $\mathrm{O} 2$ dibandingkan dengan bahan bakar premium murni pada putaran stasioner. Bahan bakar E5 merupakan variasi yang paling mereduksi emisi dibandingkan variasi bahan bakar yang lain. Pada putaran stasioner konsentrasi CO hanya 5,46\% Vol, dan HC hanya 338 ppm.
\end{abstract}

Kata kunci: Emisi gas buang, Bioetanol, Premium.

\section{PENDAHULUAN}

Perkembangan teknologi otomotif sebagai alat transportasi, baik di darat maupun di laut, sangat memudahkan manusia dalam melaksanakan suatu pekerjaan. Selain mempercepat dan mempermudah aktivitas manusia, pemakaian kendaraan bermotor juga menghasilkan dampak yang buruk terhadap lingkungan. Gas buang hasil pembakaran yang tidak sempurna akan menghasilkan zat-zat beracun dan berbahaya terhadap kesehatan manusia dan lingkungan.

Penggunaan kendaraan bermotor dalam kehidupan manusia tidak bisa dikurangi, seiring dengan semakin meningkatnya jumlah penduduk. Ironisnya polusi udara yang terjadi belakangan ini diperparah dengan peningkatan populasi kendaraan bermotor dan konsumsi BBM (Bahan Bakar Minyak). Cadangan minyak dunia yang semakin menipis merupakan salah satu permasalahan dunia akhir-akhir ini. Kondisi ini menimbulkan banyak pengaruh terhadap segala bidang baik sosial, ekonomi, politik dan keamanan.

Disamping itu, ancaman terhadap kondisi lingkungan oleh zat beracun seperti karbondioksida $\left(\mathrm{CO}_{2}\right)$, sebagai akibat dari pemakaian BBM. Salah satu usaha pemerintah Indonesia untuk mengatasi masalah tersebut adalah dengan menggunakan biofuel etanol atau bioetanol sebagai pengganti bahan bakar fosil. Menurut Prasetyo (2009), bioetanol dapat mengurangi emisi gas $\mathrm{CO}_{2}$ dengan mengurangi pembakaran hidrokarbon yang dapat menyebabkan polusi udara di sekitar kita. Karena bioetanol mempunyai tekanan uap yang lebih rendah daripada bensin, maka tekanan uap campuran (gasohol) akan lebih tinggi jika dibandingkan dengan bioetanol murni sesuai 
dengan volume bioetanol yang ditambahkan ke dalam bensin. Penambahan bioetanol dapat mengurangi tekanan uap dari bensin sekitar 1 psi dalam perbandingan tertentu. Bioetanol memiliki banyak keuntungan baik digunakan sebagai bahan bakar dalam bentuk campuran atau murni. Panas penguapan yang tinggi, titik nyala yang rendah, perubahan volume gas yang besar, nilai kalor pembakaran spesifik yang tinggi, angka oktan yang tinggi dan karakteristik lainnya memungkinkan bioetanol dapat mencapai efisiensi yang cukup tinggi $(15 \%)$.

Menurut Purwanto (2011), bahan baku bioetanol tergolong mudah didapat seperti buah mengkudu, buah juwet, limbah buah pisang, limbah singkong, batang jagung, dan limbah nanas. Dari bahan baku di atas, peneliti tertarik untuk meneliti bioetanol berbahan baku limbah nanas mengingat kandungan karbohidrat dan glukosa yang cukup tinggi. Menurut Wijana, dkk dalam Ristiani (2008) kulit nanas mengandung 81,72 \% air; 20,87 \% serat kasar; 17,53 \% karbohidrat; $4,41 \%$ protein dan $13,65 \%$ glukosa. Dengan kandungan karbohidrat dan glukosa yang cukup tinggi tersebut maka limbah nanas memungkinkan untuk dimanfaatkan sebagai bahan baku pembuatan bahan kimia, salah satunya etanol melalui proses fermentasi. Nanas merupakan salah satu jenis buah-buahan yang banyak dihasilkan di Indonesia. Dari data statistik, produksi nanas di Indonesia untuk tahun 2009 adalah sebesar 1.558.196 ton. Dengan semakin meningkatnya produksi nanas, maka limbah yang dihasilkan akan semakin meningkat pula.

Atas dasar penjelasan dan penjabaran di atas, maka peneliti tertarik untuk melakukan penelitian tentang uji emisi sepeda motor Honda Supra X 125-R tahun 2006 dengan menggunakan bioetanol dari limbah nanas dengan takaran E0; E2,5; E5; dan E7,5, dan premium sebagai campuran bahan bakar. Diharapkan penggunaan bioethanol dengan premium dapat mereduksi emisi gas buang pada kendaraan bermotor.

Rumusan masalah dari latar belakang di atas adalah bagaimana pengaruh bioetanol dari limbah nanas terhadap kadar emisi gas buang pada sepeda motor Supra X 125-R, serta Berapa perbandingan campuran bioetanol dengan premium yang ideal (menghasilkan emisi paling rendah) pada mesin sepeda motor Honda Supra X 125-R.

Tujuan dari penelitian ini meliputi, Untuk mengetahui pengaruh penggunaan bioetanol terhadap kadar emisi gas buang pada sepeda motor Honda Supra X 125-R. serta Memperoleh perbandingan campuran bioetanol dengan premium yang ideal (menghasilkan emisi paling rendah) pada motor bensin. Untuk mengetahui karakteristik bioetanol limbah nanas terhadap pengujian emisi gas buang $\mathrm{CO}, \mathrm{CO}_{2}, \mathrm{HC}$ dan $\mathrm{O}_{2}$.

\section{METODE PENELITIAN}

Penelitian ini digolongkan pada penelitian eksperimen yang berusaha membandingkan hasil penelitian dari kelompok standar dengan kelompok eksperimen. Penelitian ini bertujuan untuk mengetahui kadar emisi gas buang pada sepeda motor yang berbeda-beda pada kelompok tertentu.

Kelompok standar dalam penelitian ini adalah mesin standar motor bensin 4 langkah dengan menggunakan bahan bakar premium murni, sedangkan kelompok eksperimen penelitian adalah motor bensin 4 langkah yang menggunakan campuran bahan bakar biopremium dengan variabel penelitian sebagai berikut:

1. Bahan bakar Premium E0 (100\% premium).

2. Bahan bakar Bioetanol E2,5 (97,5\% premium $+2,5 \%$ bioetanol).

3. Bahan bakar Bioetanol E5 (95\% premium $+5 \%$ bioetanol).

4. Bahan bakar Bioetanol E7,5 (92,5\% premium $+7,5 \%$ bioetanol). 


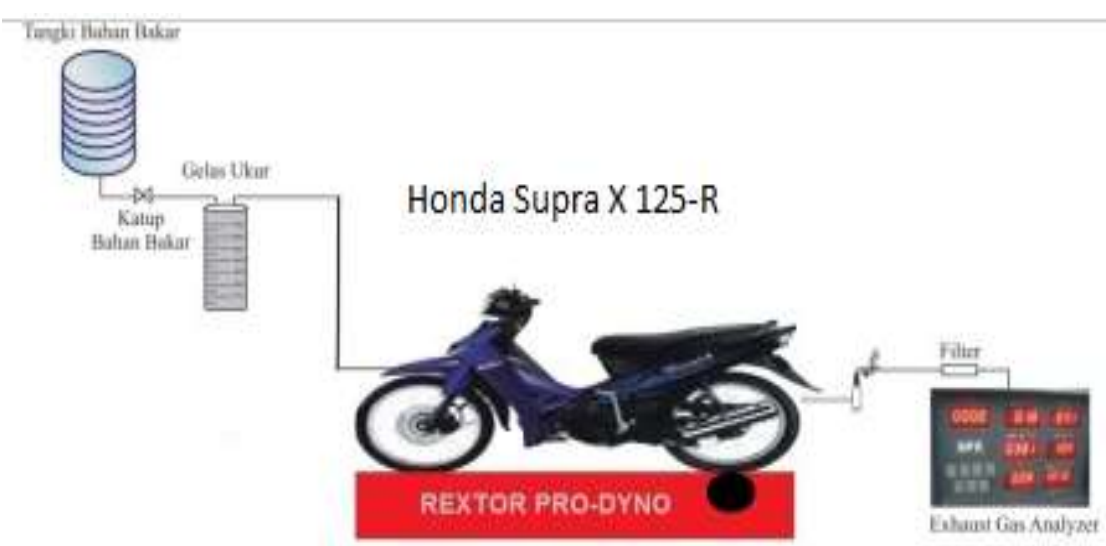

\section{Instrument Penelitian}

Gambar 1. Instrument Penelitian

Instrumen yang akan digunakan dalam penelitian ini adalah:

1. Honda Supra X 125-R

Mesin yang digunakan dalam penelitian ini adalah mesin sepeda motor Honda Supra X 125-

$\mathrm{R}$, dengan spesifikasi sebagai berikut:
a. Merk/Type /BBM
: Honda/NF125 SD, SOHC, 2 Klep/Bensin
b. Diameter $\mathrm{x}$ Langkah
: $51,0 \times 54,0 \mathrm{~mm}$
c. Volume Silinder
$: 125 \mathrm{cc}$
d. Jumlah Silinder
: 1 (satu) Silinder
e. Perbandingan Kompresi
$: 9.3: 1$
f. Tenaga Maksimum
: 9,0 PS pada putaran $8000 \mathrm{rpm}$
g. Torsi Maksimum
: 9,2 N.m pada putaran $5000 \mathrm{rpm}$

2. Exhaust Gas Analyzer

Exhaust gas analyzer adalah alat yang digunakan untuk mengukur kadar polutan gas buang yang merupakan hasil dari proses pembakaran mesin. Adapun spesifikasinya adalah:
a. Merk
: Qrotech
b. Type
: GRO-401
c. No. Seri
: F709208
d. Tahun Pembuatan : 2009
e. Pembuatan : Korea
f. Waktu Pemasangan :10 menit
g. ISO : 9001
h. Aliran Gas : 4 liter/menit
i. Aliran Gas minimal : 2.5 liter/menit
j. Rentang pengukuran :
$>\mathrm{CO}$
: $0 \div 9,99 \%$ vol
$>\mathrm{CO}_{2}$
$: 0 \div 19,9 \%$ vol
$>\mathrm{HC}$
: $0 \div 9999 \% \mathrm{ppm}$
$>\mathrm{O}_{2}$
$: 0.5 \div 5.1 \%$
$>$ Rpm Counter
: $300 \div 9990 / \mathrm{mn}$

3. Gelas Ukur

Gelas ukur digunakan untuk mengukur banyaknya pemakaian bahan bakar dari suatu mesin. Dalam pengujian ini menggunakan gelas ukur dengan kapasitas $500 \mathrm{ml}$.

4. Tangki Bahan Bakar 
Tangki bahan bakar digunakan untuk menampung bahan bakar yang akan digunakan dalam pengujian.

5. Stopwatch

Fungsi stopwatch sebagai alat bantu dalam menghitung waktu konsumsi bahan bakar pada saat pengujian. Spesifikasi stopwatch yang digunakan adalah:
$>$ Merk
: Nokia.
$>$ Penunjukan Data
: Digital.
$>$ Ketelitian
: 0,01 detik.

\section{Prosedur Penelitian}

$>$ Persiapan Sebelum Penelitian

Tahap awal yang perlu dilakukan adalah persiapan bahan yang akan digunakan dalam penelitian antara lain mempersiapkan bahan bakar premium murni E0; E2,5; E5; dan E7,5 kemudian mempersiapkan alat-alat yang dibutuhkan.

$>$ Persiapan alat ukur

Alat ukur yang akan digunakan dalam penelitian, terlebih dahulu diperhatikan spesifikasinya dan dikalibrasi agar diperoleh data-data yang valid. Antara lain alat yang digunakan adalah Exhaust Gas Analyzer, Stop Watch, Tanki Bahan Bakar dan gelas ukur.

Pengujian Emisi Gas Buang

Pengujian kelompok standar dengan bahan bakar premium murni E0, kelompok eksperimen E2,5; E5; dan E7,5 adalah sebagai berikut :

a. Mesin dihidupkan pada putaran idle $( \pm 1.500 \mathrm{rpm})$ sampai mesin mencapai kondisi kerja $\left(60-80{ }^{\circ} \mathrm{C}\right)$.

b. Membuka throttle valve secara perlahan hingga terbuka penuh.

c. Melakukan pencatatan data yang meliputi emisi gas pada Putaran mesin yaitu stasioner (1.500 rpm), $3.000 \mathrm{rpm}$, sampai $8.500 \mathrm{rpm}$ dengan rentang (range) putaran $500 \mathrm{rpm}$ pada mesin 4 langkah.

d. Mengulang percobaan sebanyak tiga kali dengan rentang waktu 20 detik.

e. Mesin dimatikan.

\section{HASIL DAN PEMBAHASAN}

Setelah melakukan penelitian, penulis akan menyajikan hasil penelitian karakteristik bahan bakar yang dilakukan di Laboratorium Bahan Bakar dan Pelumas Pertamina Unit Produksi Pelumas Surabaya (UPPS). Pengujian emisi gas buang menggunakan bahan bakar campuran premium dengan bioetanol dari limbah nanas dilakukan di Laboratorium Teknik Otomotif Universitas Negeri Padang. Tahapan pengujian karakteristik bahan bakar meliputi kandungan timbal, Reid Vapour Pressure (RVP), getah purwa (Existent Gum), kandungan sulfur. Pengujian emisi gas buang meliputi $\mathrm{CO}, \mathrm{CO}_{2}, \mathrm{HC}, \mathrm{O}_{2}$, dan Lamda $(\lambda)$. Secara lengkap, data hasil pengujian karakteristik bahan bakar dan emisi gas buang campuran bioetanol dari limbah nanas dengan premium pada sepeda motor Supra X $125 \mathrm{R}$ akan dianalisis sebagai berikut. 


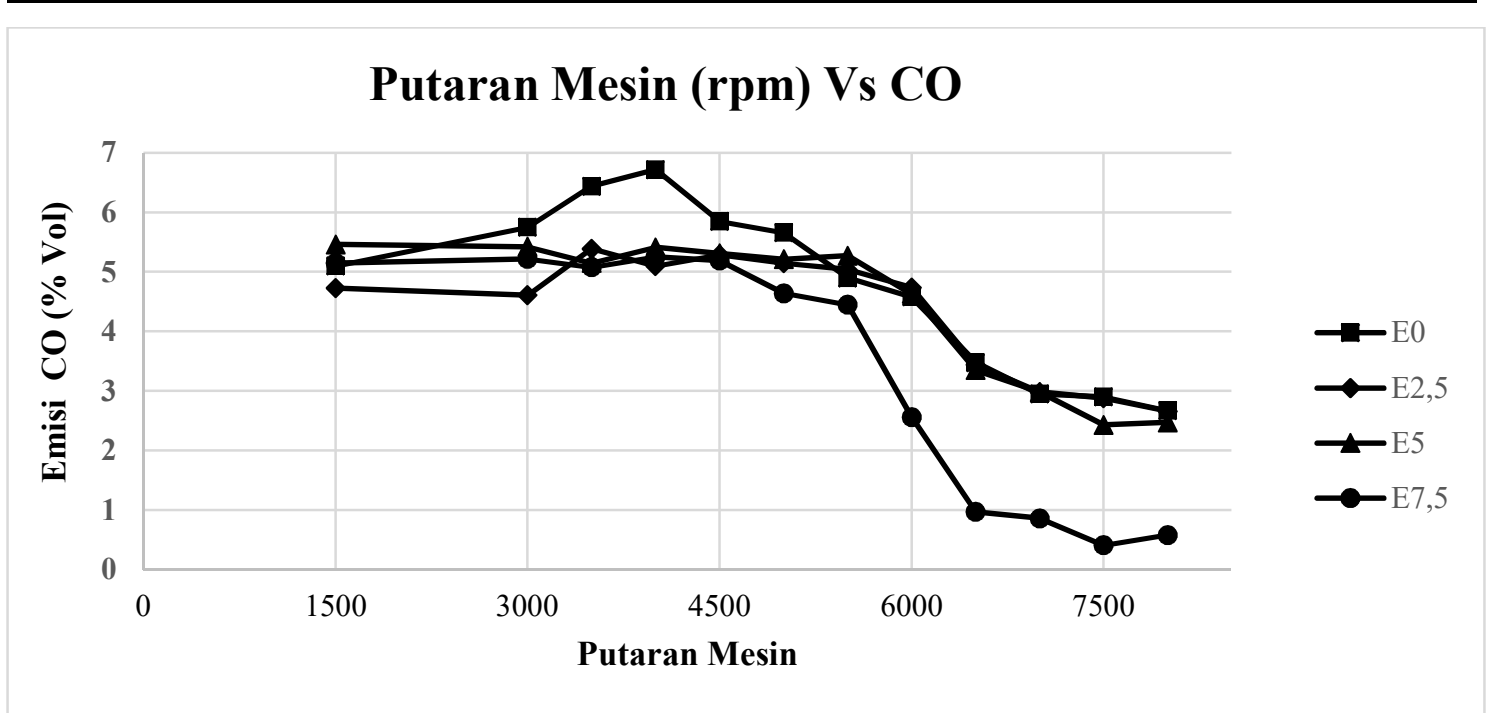

Gambar 2. Grafik putaran mesin (rpm) terhadap konsentrasi CO

Gambar 2 menunjukkan bahwa konsentrasi CO untuk premium pada putaran $1500 \mathrm{rpm}$ sebesar $5.10 \%$ vol dan kenaikan sampai pada putaran $4000 \mathrm{rpm}$ yaitu sebesar $6.72 \%$ vol hal ini disebabkan karena terjadi perubahan lamda yang mendekati normal sehingga unsur oksigen dalam pembakaran semakin berkurang sehingga tidak bisa bereaksi menjadi $\mathrm{CO}_{2}$. Pada putaran 4500 - $8000 \mathrm{rpm}$ konsentrasi $\mathrm{CO}$ terus mengalami penurunan seiring dengan lamda yang semakin mendekati normal atau pembakaran stoikiometri. Sedangkan biopremium yang menghasilkan konsentrasi CO terendah adalah E7,5 dengan konsentrasi CO maksimum 0,41\% vol.

Pada gambar 3 untuk pengujian bahan bakar premium pada putaran $1500 \mathrm{rpm}$ menunjukkan konsentrasi $\mathrm{CO}_{2}$ paling rendah yaitu sebesar $3.2 \%$ vol terus mengalami kenaikan hingga putaran $8000 \mathrm{rpm}$ yaitu sebesar $12.2 \%$ vol.

Gambar 4 menunjukkan bahwa kadar emisi gas buang HC tertinggi terdapat pada bahan bakar premium terjadi pada putaran $1500 \mathrm{rpm}$ sebesar $568 \mathrm{ppm}$ yang menandakan campuran yang kekurangan bahan bakar. Sehingga pada proses pembakaran terjadi kelebihan oksigen dan menyebabkan pembakaran yang tidak sempurna. Pada putaran 3000 - $8000 \mathrm{rpm}$ konsentrasi HC mengalami penurunan hingga $69 \mathrm{ppm}$. Hal tersebut menandakan campuran udara dan bahan bakar yang mendekati stoikiometri menghasilkan konsentrasi $\mathrm{HC}$ yang semakin rendah pada gas buang.

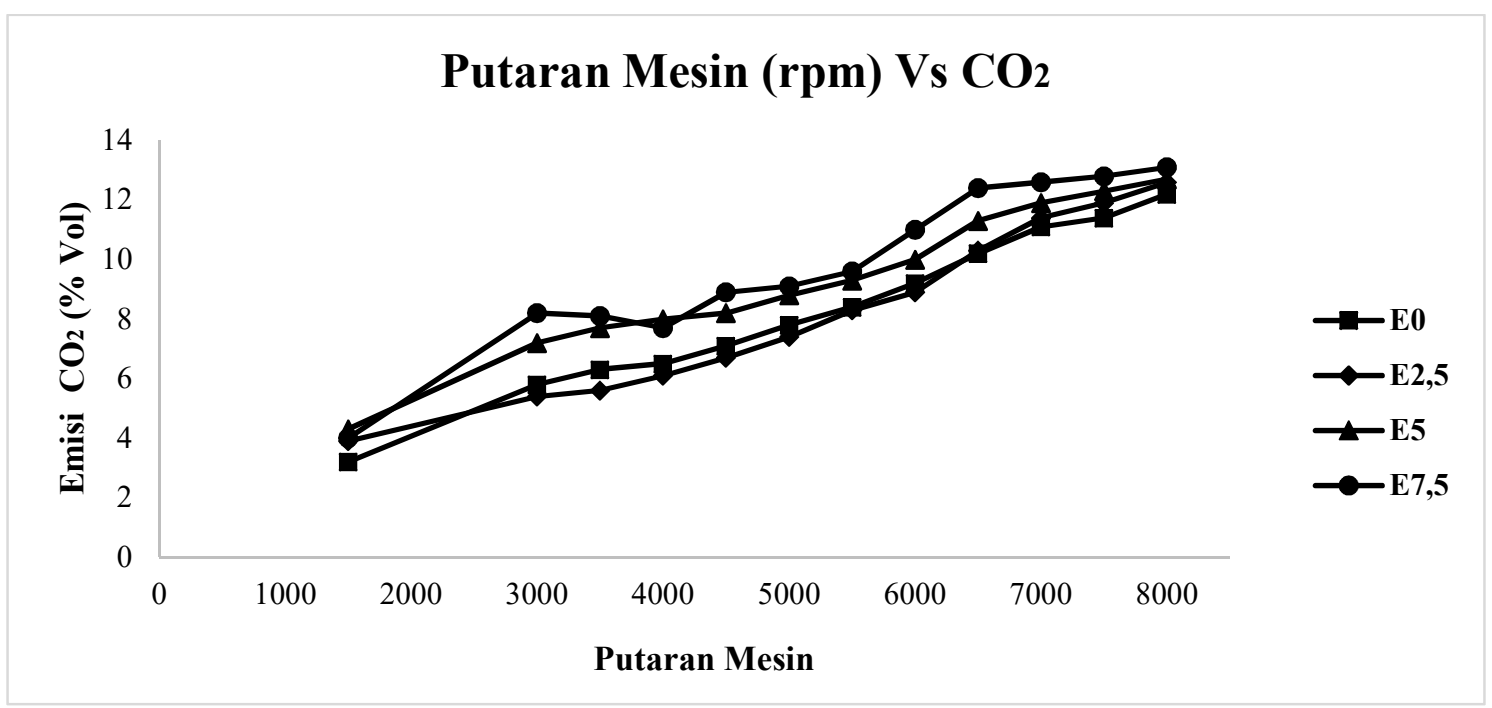

Gambar 3. Grafik putaran mesin (rpm) terhadap konsentrasi $\mathrm{CO}_{2}$ 


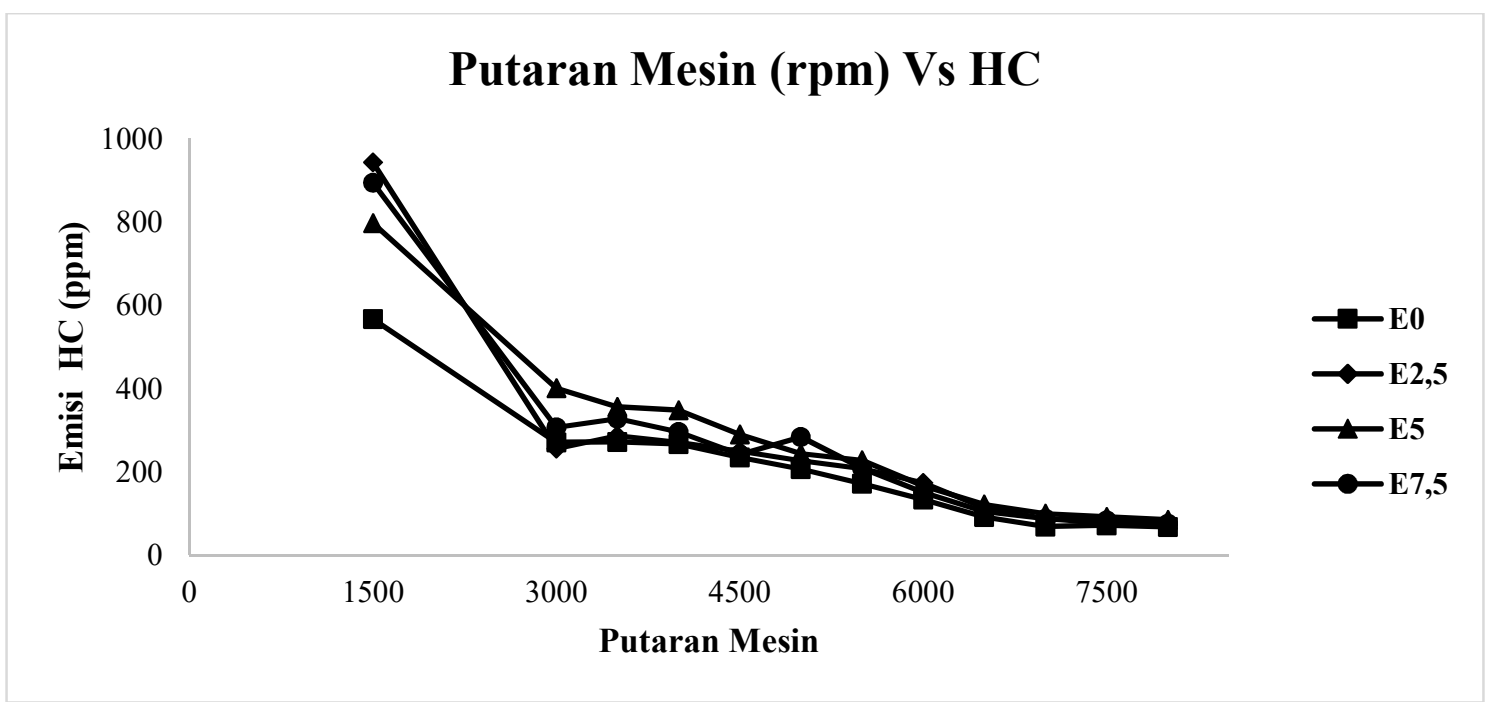

Gambar 4. Grafik putaran mesin (rpm) terhadap konsentrasi HC

Untuk bahan bakar bioetanol E2,5 - E7,5 terjadi peningkatan konsentrasi HC, tertinggi dihasilkan oleh bioetanol E2,5 pada putaran $1500 \mathrm{rpm}$ sebesar 895 ppm. Kandungan HC pada putaran 3000 - 8000 terus mengalami penurunan seiring dengan nilai lamda yang mendekati normal, hingga konsentrasi HC paling rendah dihasilkan oleh bioetanol E7,5 sebesar $77 \mathrm{ppm}$. Hal tersebut menunjukkan bahwa semakin baik nilai lamda maka semakin kecil pula konsentrasi HC yang dihasilkan pada gas buang.

Gambar 5 Menunjukkan konsentrasi $\mathrm{O}_{2}$ tertinggi pada bahan bakar premium terjadi pada putaran $1500 \mathrm{rpm}$ sebesar $11,51 \%$, hal tersebut dipengaruhi oleh nilai lamda yang besar dan menunjukkan campuran terjadi kelebihan oksigen sehingga terdapat sisa oksigen dalam pembakaran yang tidak terdapat dan menghasilkan konsentrasi $\mathrm{O}_{2}$ yang tinggi pada gas buang. Pada putaran 3000 - $8000 \mathrm{rpm}$ konsentrasi $\mathrm{O}_{2}$ semakin kecil hingga 1,4\%, hal tersebut menunjukkan bahwa nilai lamda semakin mendekati stoikiometri maka konsentrasi $\mathrm{O}_{2}$ yang dihasilkan juga semakin kecil karena oksigen yang masuk ke ruang bakar dimanfaatkan sepenuhnya untuk proses pembakaran.

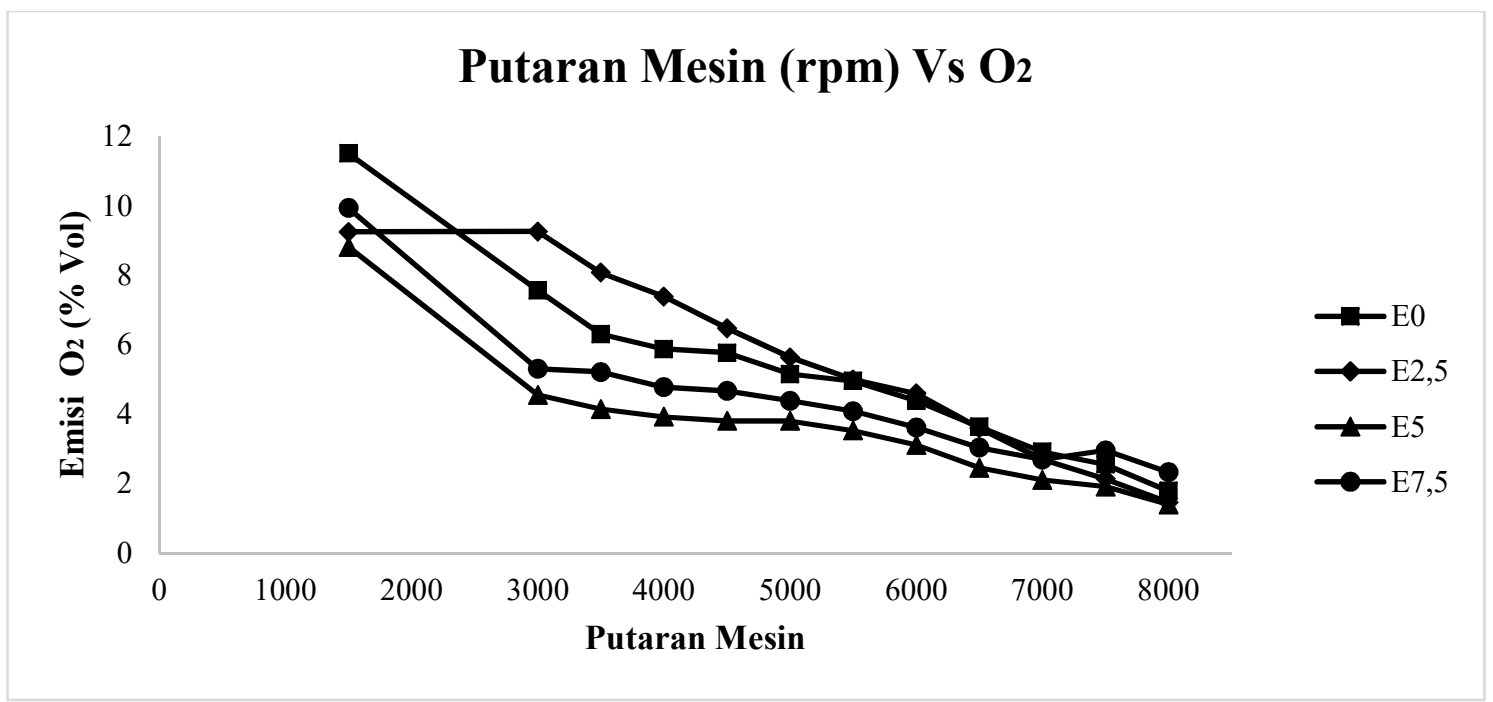

Gambar 5. Grafik putaran mesin (rpm) terhadap konsentrasi $\mathrm{O}_{2}$ 
Untuk bahan bakar biopremium E5 - E7,5 terjadi penurunan konsentrasi $\mathrm{O}_{2}$ yang cukup besar, pada putaran $1500 \mathrm{rpm}$ penurunan paling besar terdapat pada bahan bakar bioetanol E5 dengan konsentrasi $\mathrm{O}_{2}$ sebesar $8,82 \%$. Pada putaran $3000-8000 \mathrm{rpm}$ konsentrasi $\mathrm{O}_{2}$ pada bioetanol E2,5 - E7,5 terus mengalami penurunan. Untuk bahan bakar biopremium E2,5 pada putaran $1500 \mathrm{rpm}$ terjadi penurunan konsentrasi $\mathrm{O}_{2}$ terhadap premium yaitu sebesar $9,25 \%$. Pada putaran $3000-6000 \mathrm{rpm}$ terjadi peningkatan konsentrasi $\mathrm{O}_{2}$ yaitu sebesar 9,26 - 4,60\%, peningkatan ini diakibatkan oleh nilai lamda yang semakin besar menunjukkan dalam pembakaran terjadi kelebihan udara sehingga terdapat unsur oksigen yang tidak terbakar dan ikut keluar dalam gas buang. Pada putaran $6500-8000 \mathrm{rpm}$ konsentrasi $\mathrm{O}_{2}$ turun hingga 1,46\% mengindikasikan jumlah udara yang masuk dalam pembakaran digunakan sepenuhnya untuk proses pembakaran.

Lamda mengindikasikan seberapa besar penyimpangan jumlah udara dalam campuran udara dan bahan bakar yang sesungguhnya terhadap jumlah kebutuhan udara teoritis. Pada gambar 6 bisa kita ketahui besarnya lamda untuk tiap jenis bahan bakar. Jika nilai lamda kurang dari satu $(\lambda<1)$ menandakan campuran kaya yang berarti dalam campuran mengandung terlalu banyak bahan bakar, jika nilai lamda sama dengan $1(\lambda=$ 1) menandakan campuran normal yang berarti komposisi campuran udara dan bahan bakar sedah sesuai dengan kebutuhan, sedangkan jika nilai lamda lebih dari satu $(\lambda>1)$ menandakan campuran kurus yang berarti dalam campuran bahan bakar mengandung terlalu banyak udara.

Untuk bahan bakar premium pada putaran 1500 - 7500 rpm menunjukkan nilai lamda yang tinggi yaitu sebesar 1,598-1,048. Pada putaran tersebut terjadi campuran miskin dimana jumlah udara yang terdapat pada campuran terlalu besar. Nilai lamda untuk bahan bakar premium nilai mendekati normal pada putaran 8000 rpm sebesar 1,001.

Untuk bahan bakar biopremium E2,5 - E7,5 pada putaran 1500 menghasilkan nilai lamda yang tinggi tetapi masih dibawah premium, untuk biopremium E2,5 sebesar 1,250, E5 sebesar 1,220 , dan E7,5 sebesar 1,356, Hal tersebut mengindikasikan dengam penambahan biopremium maka campuran udara dan bahan bakar mendekati normal. Nilai lamda mulai mendekati normal untuk bahan bakar biopremium E2,5 terjadi pada putaran $7500 \mathrm{rpm}$ sebesar 1,010, E5 terjadi pada putaran $7000 \mathrm{rpm}$ sebesar 1,005, E7,5 terjadi pada putaran $4000 \mathrm{rpm}$ sebesar 1,013.

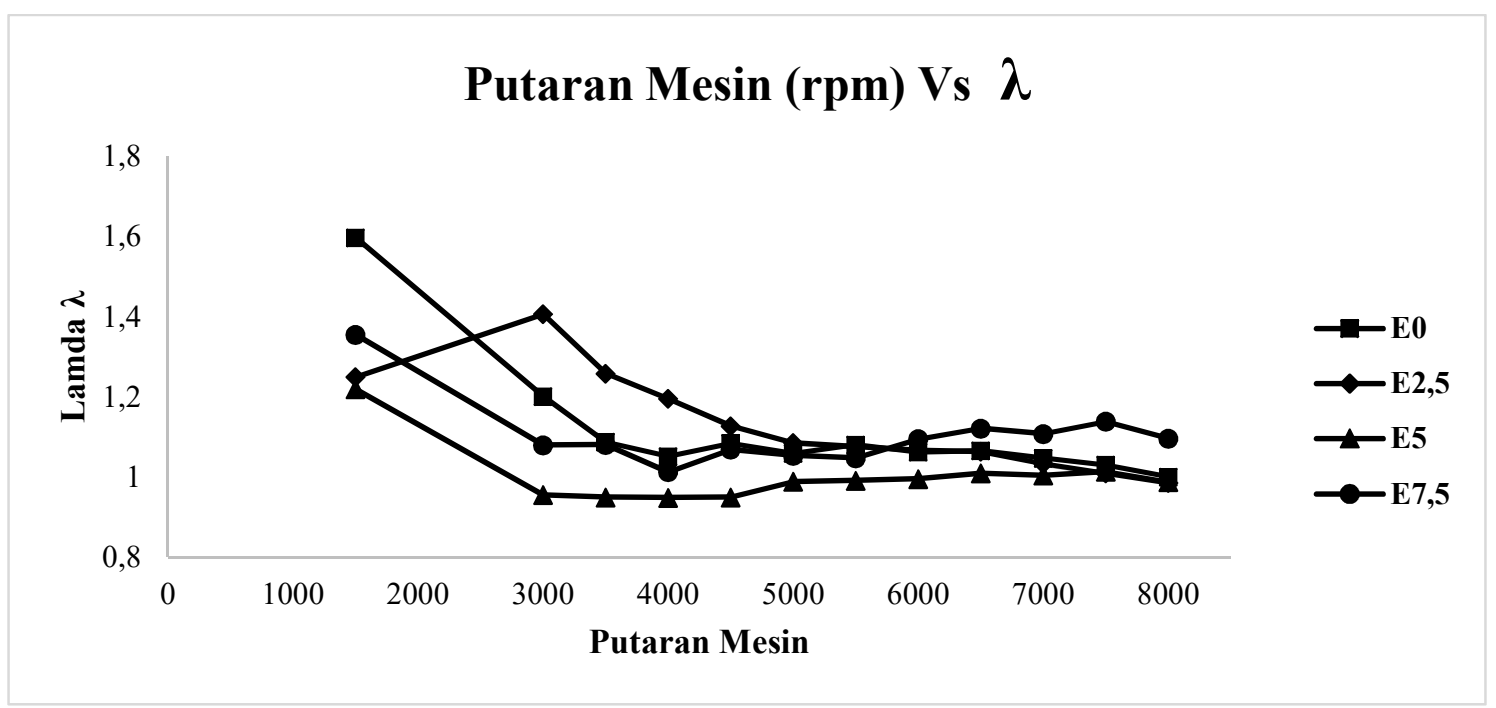

Gambar 6. Grafik putaran mesin (rpm) terhadap nilai lamda

\section{KESIMPULAN}


Pengaruh penggunaan bioetanol dari limbah nanas terhadap kadar emisi gas buang pada Sepeda Motor Supra X 125 R berdasarkan hasil pengujian menunjukkan emisi gas buang yang lebih ramah lingkungan dari pada premium. Dimana hasil pengujian emisi gas buang untuk bahan bakar premium menghasilkan konsentrasi CO maksimum sebesar $5.10 \%$ vol, sedangkan biopremium yang menghasilkan konsentrasi CO terendah adalah E5 dengan konsentrasi CO maksimum $0,75 \%$ vol. Bahan bakar premium menghasilkan konsentrasi $\mathrm{HC}$ tertinggi sebesar 568 ppm, sedangkan konsentrasi HC tertinggi bahan bakar biopremium E2,5 sebesar 944 ppm. Perbandingan yang sesuai untuk penggunaan bahan bakar bioetanol dari limbah nanas sebagai campuran premium terhadap emisi gas buang pada putaran stationer yang E7,5 dengan konsentrasi CO sebesar 5,46\% vol dan konsentrasi HC sebesar 338 ppm, sedangkan E2,5 menghasilkan konsentrasi CO tertinggi sebesar 4,27\% vol, HC 944 ppm. E5 dengan CO 5.46\% vol dan HC 798 ppm. E7,5 dengan CO 5.15 \% vol dan HC 895 ppm. Dengan demikian dapat kita lihat untuk bahan bakar dengan kadar gas buang beracun yang paling rendah ada pada bahan bakar E5.

\section{DAFTAR PUSTAKA}

[1] Bosch, Robert. 2001. Gasoline-Engine Management, Basics and Components. Stuttgard: Robert Bosch GmbH.

[2] Erjavec, Jack. 2000. Automotive Technology, A System Approach. London: Thomson Learning.

[3] Halderman, James D, dan Jim Linder. 2006. Automotive Fuel and Emissions Control Systems. New Jersey: Pearson Education, Inc.

[4] Handayani, Sri Utami. Tanpa Tahun. Pemanfaatan Bio Ethanol Sebagai Bahan Bakar Pengganti Bensin. Semarang: Universitas Diponegoro.

[5] Heisler, Heinz. 1995. Advanced Engine Technology. London: Hodder Headline PLC.

[6] Obert, Edwart F. 1973. International Combustion Engine and Air Pollution (3rd.Ed). New York: Harper \& Row Publishers, Inc.

[7] Prasetyo, Devanta B dan Patriayudha, F. 2009. Pemakaian Gasohol Sebagai Bahan Bakar Pada kendaraan Bermotor. Semarang: Universitas Diponegoro.

[8] Pratama, Yudhi. 2010. Uji Emisi Penggunaan Bioetanol Dari Pucuk Tebu Sebagai Campuran Premium Terhadap Mesin 4 Langkah. Surabaya: Universitas Negeri Surabaya.

[9] Purwanto, Agus. 2011. Pengaruh Jumlah Ragi dan Lama Fermentasi Terhadap Kadar Etanol dari Kulit Nanas Sebagai Bahan Bakar Alternatif. Surabaya: Universitas Negeri Surabaya

[10] Ristiani, juwita, dkk. 2008. Sintesis Etanol Dari Sari Kulit Nanas (Ananas comosus L. Merr) Sebagai Pengganti Bahan Bakar Cair. Semarang: Universitas Negeri Semarang.

[11] Schäfer, Fred dan Richard Van Basshuysen. 1995. Reduced Emission and Fuel Consumption in Automobile Engines. New York: SAE. 